\title{
Annual Analysis of Competitiveness, Simulation Studies and Development Perspective for 34 Greater Ghina Economies: 2000-2010
}


This page intentionally left blank 


\title{
Annual Analysis of Competitiveness, Simulation Studies and Development Perspective for 34 Greater Ghina Economies: 2000-2010
}

\author{
Tan Khee Giap \\ Co-Director, Asia Competitiveness Institute \\ Lee Kuan Yew School of Public Policy \\ National University of Singapore, Singapore \\ Yuan Randong \\ Research Assistant, Asia Competitiveness Institute \\ Lee Kuan Yew School of Public Policy \\ National University of Singapore, Singapore \\ Sangiita Yoong Wei Cher \\ Research Assistant, Asia Competitiveness Institute \\ Lee Kuan Yew School of Public Policy \\ National University of Singapore, Singapore \\ Yang $\mathrm{Mu}$ \\ Senior Research Fellow, Asia Competitiveness Institute \\ Lee Kuan Yew School of Public Policy \\ National University of Singapore, Singapore
}

\section{Tang Min}

Counsellor, the State Council; Executive Vice-Chairperson, YouChange China Social Entrepreneur Foundation; and Council Member, China Council for International Cooperation on Environment and Development People's Republic of China

\section{Zhang Jun}

Director, China Center for Economic Studies and Vice Dean, Fudan Development

Institute, Fudan University

People's Republic of China

- Reviewers -

\section{Wei Houkai}

Deputy Director, Institute for Urban and Environmental Studies Chinese Academy of Social Sciences (CASS)

People's Republic of China

\section{Zuo Xiaolei}

Chief Advisor to the President, China Galaxy Securities Company Ltd, People's Republic of China

\section{David Hong}

President, Taiwan Institute of Economic Research and Chair, Chinese Taipei Pacific Economic Cooperation Committee Chinese Taipei 


\section{Published by}

World Scientific Publishing Co. Pte. Ltd.

5 Toh Tuck Link, Singapore 596224

USA office: 27 Warren Street, Suite 401-402, Hackensack, NJ 07601

UK office: 57 Shelton Street, Covent Garden, London WC2H 9HE

\section{British Library Cataloguing-in-Publication Data}

A catalogue record for this book is available from the British Library.

\section{ANNUAL ANALYSIS OF COMPETITIVENESS, SIMULATION STUDIES AND DEVELOPMENT PERSPECTIVE FOR 34 GREATER CHINA ECONOMIES: 2000-2010}

Copyright (C) 2014 by World Scientific Publishing Co. Pte. Ltd.

All rights reserved. This book, or parts thereof, may not be reproduced in any form or by any means, electronic or mechanical, including photocopying, recording or any information storage and retrieval system now known or to be invented, without written permission from the publisher.

For photocopying of material in this volume, please pay a copying fee through the Copyright Clearance Center, Inc., 222 Rosewood Drive, Danvers, MA 01923, USA. In this case permission to photocopy is not required from the publisher.

ISBN 978-981-4579-42-1

In-house Editor: Elizabeth Lie

Typeset by Stallion Press

Email: enquiries@stallionpress.com 


\section{ABOUT ACI}

The Asia Competitiveness Institute (ACI) was established in August 2006 as a research centre at the Lee Kuan Yew School of Public Policy, National University of Singapore. It aims to build the intellectual leadership and network for understanding and developing competitiveness in the ASEAN region. ACI seeks to contribute to the enhancement of economic growth and living standards through competitiveness research on clusters and comparative regions. It identifies mitigating issues and challenges for potential policy interventions.

\section{VISION AND MISSION}

- The over-arching vision of ACI is to build up its research credibility with policy impact, contributing as a professional think-tank.

- The mission is to establish our niche as a leading policy think-tank in Asia by identifying competitiveness, promoting competition and synergizing complementarities amongst Asian economies.

- We would articulate, entice discourse and shape agenda on arena of public policies amongst Asian governments.

- We would undertake evidence-base assessment on public policy outcomes, their effectiveness and inclusive impacts.

- Two key regional focuses are:

I. Identify trends of competitiveness and policy analysis on trade and investment of ASEAN, within the regional context of competition and complementarities with China and India.

II. Identify competitive strengths and conduct policy analysis on Singapore within the context of regional economies with international benchmarking. 


\title{
FOUNDING PATRON AND INTERNATIONAL ADVISORY PANEL
}

\author{
Founding Patron: Mr George Yeo \\ Visiting Scholar, Lee Kuan Yew School of Public Policy, National \\ University of Singapore \& Former Minister of Foreign Affairs, \\ Singapore
}

\author{
International Advisory Panel \\ Co-Chairs: $\quad$ Professor Michael Porter \\ Bishop William Lawrence University Professor \\ Ms Marjorie Yang \\ Chairman, Esquel Group \\ Members: $\quad$ Professor Kishore Mahbubani \\ Dean, Lee Kuan Yew School of Public Policy, National University \\ of Singapore \\ Dr Kuntoro Mangkusubroto \\ Head, President's Delivery Unit for Developing Monitoring \\ and Oversight (UKP4), Indonesia \\ Mr Narayana Murthy \\ Chairman, Infosys Technologies Limited \\ Mr Philip Yeo \\ Chairman, SPRING Singapore \\ Mrs Ow Foong Pheng \\ Permanent Secretary, Ministry of Trade and Industry \\ Ms Yong Ying-I \\ Permanent Secretary, Public Service Division \\ Professor Chan Kam Leung Alan \\ Dean, College of Humanities, Arts and Social Sciences, Nanyang \\ Technological University
}

Asia Competitiveness Institute

Lee Kuan Yew School of Public Policy, National University of Singapore

469C Bukit Timah Road, Wing A, Level 3, Oei Tiong Ham Building,

Singapore 259772

Tel: (65) 65165025 Fax: (65) 67756471

Email: ACI@nus.edu.sg http://lkyspp.nus.edu.sg/ACI 


\section{Contents}

Foreword $\quad$ ix

Preface - xi

Acknowledgements xiii

List of Economies $\quad \mathrm{xV}$

List of Abbreviations $\quad$ xvii

Directory of Tables and Figures xix

Chapter 1 Annual Analysis of Competitiveness, Simulation Studies and

Development Perspective for 34 Greater China Economies: An Overview 1

Review 1: Working Hard to Further Improve Competitiveness

by Dr Tang Min, Counsellor, the State Council \&

Executive Vice-Chairperson, YouChange China Social

Entrepreneur Foundation \& Council Member,

China Council for International Cooperation on

Environment and Development, People's Republic of China

Review 2: A Review of the "Annual Analysis of Competitiveness, Simulation Studies and Development Perspective for

34 Greater China Economies: 2000-2010” by Dr Zhang Jun,

Director, China Center for Economic Studies \& Vice Dean,

Fudan Development Institute, Fudan University, People's

Republic of China

Review 3: Factor Endowments, Regional Transitions and Competitiveness

Cycles - A review of the "Annual Analysis of Competitiveness,

Simulation Studies and Development Perspective for 34 Greater

China Economies: 2000-2010” by Dr Wei Houkai,

Deputy Director, Institute for Urban and Environmental Studies,

Chinese Academy of Social Sciences (CASS), People's

Republic of China

Review 4: Financial Reforms, Internationalization of RMB and the

Shanghai International Financial Centre by Dr Zuo Xiaolei,

Chief Advisor to the President, China Galaxy Securities

Company Ltd, People's Republic of China

Chapter 2 Anhui (安徽)

Chapter 3 Beijing (北京)

Chapter 4 Chongqing (重庆)

Chapter 5 Fujian (福建) 
Chapter 6 Gansu (甘肃)

Chapter 7 Guangdong (广东)

Chapter 8 Guangxi (广西)

Chapter 9 Guizhou (贵州)

Chapter 10 Hainan (海南)

Chapter 11 Hebei (河北)

Chapter 12 Heilongjiang (黑龙江)

Chapter 13 Henan (河南)

Chapter 14 Hong Kong (香港)

Chapter 15 Hubei (湖北)

Chapter 16 Hunan (湖南)

Chapter 17 Inner Mongolia (内蒙古)

Chapter 18 Jiangsu (江苏) 575

Chapter 19 Jiangxi (江西) 605

Chapter 20 Jilin (吉林) 635

Chapter 21 Liaoning (辽宁) 667

Chapter 22 Macau (澳门)

Chapter 23 Ningxia (宁夏) 725

Chapter 24 Qinghai (青海)

Chapter 25 Shaanxi (陕西) 795

Chapter 26 Shandong (山东) 829

Chapter 27 Shanghai (上海) 863

Chapter 28 Shanxi (山西) 897

Chapter 29 Sichuan (四川)

927

Chapter 30 Taiwan (台湾)

959

Chapter 31 Tianjin (天津)

989

Chapter 32 Tibet (西藏)

1021

Chapter 33 Xinjiang (新疆)

1049

Chapter 34 Yunnan (云南)

1079

Chapter 35 Zhejiang (浙江)

Appendix 1 List of Indicators

Appendix 2 Computation of Rankings: The Algorithm 


\section{Foreword}

In terms of economics, competitiveness is a general capability that is expressed as competition between two or more participants. Regional competitiveness refers to the formation and expression of the fight over resources or market capabilities between economic entities in a region in the process of market competition. It also can refer to the capability of a region to optimize resource allocation compared to other similar regions within a larger region.

A country that wishes to transition from being a follower to a leader must develop at an unusually rapid rate and must be more competitive than most other countries during the same period. Since China implemented its reform and opening up policy in 1978, the country has seen a wave of modernization and globalization. This is the first time in history that a country's growth rate has remained the fastest in the world for 30 years in a row and in the double digits.

The miracle of East Asian started with Japan and the Four Asian Tigers and has continued in China with its 1.3 billion strong population and 30 years of rapid growth, making the miracle even more impressive. The first part of this miracle was a supply chain and manufacturing hub based in East Asia and with its core in China. The second is the rapid growth of the middle class in China, East Asia and Southeast Asia, making this region one of the most important markets in the world. Third is the fact that East Asia and China are becoming new drivers in the world economy, providing capital, technology and solutions. China and East Asia are currently surpassing the United States and Europe to become the largest hub of the world economy.

If this change is put in the larger context of history, this would be China's fourth "rise" after the Qin/Han, Tang/Song and Ming/Qing eras. However, the difference with these previous three rises is that this most recent one has been due to increased competitiveness and it has taken place in the context of a more open world. It is a rise that is connected closely to East Asia and the rest of the world. As Chinese officials and academics have been saying since the 1980s, reform and opening up in China are mutually dependent and inseparable. "Reform and opening up is the source of China's contemporary development and without it, China would not be where it is today." ${ }^{1}$ From the outside, reform and opening up has changed China, while China has changed East Asia and the rest of the world.

Countries that entered late into the world economy must continually make their products and their overall economy more competitive. However, competition must strictly obey both international and domestic laws. Companies must proactively uphold fair competition in the market and promote its healthy operation. Internationally, competition cannot be separated from cooperation. Since China entered the World Trade Organisation in 2001 and created the ASEAN Free Trade Zone in 2010, as well as its current attempts to create Regional Comprehensive Economic Partnership (RCEP) relationship with 16 countries including ASEAN nations, Japan, Korea, India, Australia and New Zealand, China has learned how to open up, obey laws and cooperate.

${ }^{1}$ Gao, Shangquan, ed.: Reform is China's Greatest Asset, People's Press, Beijing 2013, p. 3. 
It has also learned how to communicate with neighbouring countries and the rest of the world to create a more harmonious community.

This report, by the Asia Competitiveness Institute of the Lee Kuan Yew School of Public Policy at the National University of Singapore, finds that China's competitiveness comes from opening up and learning from the East Asian model as well as successful experiences by other countries in the world. This, along with advanced technology, has given it the advantage of lateentry as well as to surpass Hong Kong, Macau and Taiwan. This has also helped to improve how well China uses resources and overall efficiency. This report also carries out comparison with simultaneous research done on Indonesia's 33 provinces, India's 35 states and federal territories as well as the ten countries of ASEAN, creating an evaluation model and indicator system for Overall Competitiveness, which includes an Overall Competitiveness, 4 environments, 11 subenvironments and 102 indicators. This has enabled in-depth analysis of changes in competitiveness in the 34 Greater China economies and provides policy suggestions based on the resources, development strategies and main governmental policies of these 34 economies.

China's successful experiences may have a number of important points for countries like India, Indonesia and other emerging economies that are currently up and coming and have huge domestic markets.

From another perspective, questions of whether China can maintain this fourth rise and whether it can see more success in the coming decades have been asked. The answer to these questions may not come from economic competitiveness alone. China's Twelfth Five Year Plan, released in 2010, clearly states that China must ensure and improve the livelihoods of people and that this must be the "starting point and the end point in accelerating and transitioning China's economic development model." This shows that after 30 years of rapid industrial development, China is currently in the process of paying more attention to urbanization with a focus on the livelihoods of people. In maintaining its focus on economic competitiveness and employment, China has started to also focus more on inflation, food safety, environmental protection, personal respect, social insurance, rule of law, reigning in powers and communication with international society.

The "Ranking the Liveability of the World's Major Cities: The Global Liveable Cities Index" released by the ACI in 2012 used the Global Liveable Cities Index (GLCI) concepts and models to evaluate and rank 64 world cities using over 100 indicators. We hope that they can expand this to cities in China as well as East Asia and Southeast Asia, integrating research on both regional competitiveness and liveability of cities, providing a more comprehensive, balanced, systematic and historical view and analysis on China, Indonesia, ASEAN countries and India.

Professor Wang Gungwu Chairman, Governing Board Lee Kuan Yew School of Public Policy National University of Singapore 


\section{Preface}

This book is a collection of papers and data-sets on the 34 Greater China economies. The book describes the crucial juncture at which the Greater China economies are now poised.

The socio-economic landscape of the 34 Greater China economies has experienced enormous changes over the last three decades. The growth story underpinning this transformation is said to be unparalleled in human history. Despite social, cultural and political constraints, the Greater China economies as a whole have outpaced almost every other economy. Delivering rapid economic growth in small or medium-sized societies is difficult enough, but to watch the world's most populous region experience the world's most rapid growth is like watching the largest kid in school win the 100-metre hurdles. Such progress does not happen automatically. It requires deft, sustained economic management of the kind that the leaders of these economies have displayed.

What happens in this part of the world in the next 20 years will help define what the $21 \mathrm{st}$ century means for China, Asia and the world. How the Greater China economies can maintain the growth momentum by further enhancing productivity and competiveness, how they can continuously improve their people's living standards, how they can achieve all this without incurring serious environmental costs, and whether the region will fulfil its destiny as a reenergized economic power-house with its constituent economies becoming as advanced as other developed regions of the world, all these are the focus of research currently undertaken by the Asia Competitiveness Institute (ACI), a research centre of the Lee Kuan Yew School of Public Policy (LKYSPP), National University of Singapore (NUS).

The empirical findings on the 34 economies in terms of their relative competitiveness were presented and the accompanying public policy recommendations deliberated upon at ACI's July 2012 Annual Conference. The event unveiled original data and analysis on how the economies, if led and managed decisively and efficiently, can embark on a trajectory of development that will ensure a bright future. The in-depth information that was shared at the conference and presented in this book posits a future in which hundreds of millions of more Chinese citizens are lifted out of poverty and form a middle-class that will be amongst the largest in the world. Such a development will in turn propel China into a role commensurate with its importance in the world economy and in international affairs more broadly, as is increasingly becoming evident.

At the Review Seminar held on 10 June 2013 at the LKYSPP, an engaged audience, comprising policy planners and managers, heard experts and discussants present findings on the relative economic performance of the 34 economies. These findings can be a vital guide for Greater China decision-makers as they plan for the future.

All the Greater China economies were subjected to the same rigour of competitiveness ranking. The rankings serve as points of comparison amongst the 34 economies, as each economy tracks its outputs, outcomes and achievements going forward. The information compiled here 
could be the basis for an ambitious blueprint for Greater China leaders, managers and thinkers and could usefully inform the decisions of those in Asia and beyond who deal with China.

I am proud to present this important undertaking. Much more exciting work lies ahead, and we hope that the volume will generate public policy findings, conclusions and recommendations that will help the Greater China economies realise their potential. A stable, prosperous China can only benefit the Asia-Pacific region and the world as a whole and is a goal that both ACI and the LKYSPP continue to strive towards.

Professor Kishore Mahbubani

Dean

Lee Kuan Yew School of Public Policy National University of Singapore 


\section{Acknowledgements}

We from the Asia Competitiveness Institute (ACI) at Lee Kuan Yew School of Public Policy (LKYSPP), National University of Singapore (NUS) have been tracking the competitiveness of 34 Greater China Economies, amongst many others Asian economies, since 2000. Our work includes a published volume in 2013 on Competitiveness Analysis and Development Strategies for 33 Indonesian Provinces, Annual Analysis of Competitiveness, Simulation Studies and Development Perspective for 35 States and Federal Territories of India: 2000-2010, Annual Analysis of Competitiveness, Development Strategies and Public Policies on ASEAN-10: 2000-2010, as well as for 34 Greater China Economies as in this volume.

In this book on "Annual Analysis of Competitiveness, Simulation Studies and Development Perspective for 34 Greater China Economies: 2000-2010”, we use the same unique methodology and tools as in our other studies of competitiveness. Over time, the methodology and indicators are continuously being improved, and indicators are regularly being reviewed and updated at the levels of provinces, municipalities, autonomous regions or special administrative regions. Taken together, ACI thus offers both macro provincial level economies assessment and indicators at micro level by sectors for competitiveness evaluation. Effective coordination across-the-board is ensured in the context of political economy.

Drawing from a Review Seminar held in LKYSPP, NUS held on $10^{\text {th }}$ June 2013 before the book is published, ACI received tremendous supports from various experts of 34 Greater China Economies who came from the public and private business sector. We wish to record the effort and the time taken by the reviewers in evaluating the chapters and their constructive comments are incorporated accordingly. We therefore would like to thank following Reviewers:

\section{Tang Min}

Counsellor, the State Council \& Executive Vice-Chairperson, YouChange China Social Entrepreneur Foundation \& Council Member, China Council for International Cooperation on Environment and Development, People's Republic of China

\section{Zhang Jun}

Director, China Center for Economic Studies \&

Vice Dean, Fudan Development Institute

Fudan University,

People's Republic of China

\section{Wei Houkai}

Deputy Director, Institute for Urban and Environmental Studies, Chinese Academy of Social Sciences (CASS),

People's Republic of China 


\section{Zuo Xiaolei}

Chief Advisor to the President, China Galaxy Securities Company Ltd, People's Republic of China

\section{David Hong}

President, Taiwan Institute of Economic Research \&

Chair, Chinese Taipei Pacific Economic Cooperation Committee,

Chinese Taipei

Graduates from the Master in Public Administration and Management (MPAM) programme of LKY School, NUS, have helped in collecting latest data and relevant information for the book. They are Wang Dongxia, Wang Gaifeng, Wang Yancheng, Wang Haiping, Deng Li, Ren Xiaodong, Liu Junjie, Liu Zhijun, Du Mingming, Zhang Yong, Chen Zihong, Chen Yuanxuan, Zhong Hua, Gao Xiang, Huang Yansong, Han Xuedong, Lei Yu, Bao Honglu, and Tan Nailin.

We would place on record our appreciation for the encouragement of Professor Kishore Mahbubani (Dean), Professor Kanti Prasad Bajpai (Vice Dean, Research), Mr Donald Low (Assistant Dean, Research Centres) and other colleagues in LKYSPP in making this effort possible. This book would not be conceivable without the dedicated assistance of research and administrative staff from ACI. They have been working hard throughout, organising the Review Seminar and overall rolling-out of the project. Thus we note with great appreciation the high team spirit from ACI staff including Tan Boon Seng, Harold Teng Siow Song, Yap Xin Yi, Yip Fung Yi Estelle, Tracy Cai Jiao, Ham Oi Mun, Wong Meng Khin, Loh Chao Kiat, Loh Shufang, Vicky Lee Yuen Ting, Kevin Liu Yiming, Benjamin Chiam Kai Jie, Nie Tongxin and Amanda Lim.

Last but never the least, we would like to thank World Scientific for their great effort in making this volume ready for publication. Without its assiduous staff being so meticulous and efficient, the timely launch of the book would not be plausible.

Tan Khee Giap, Yuan Randong, Sangiita Yoong Wei Cher \& Yang Mu Asia Competitiveness Institute, Lee Kuan Yew School of Public Policy 


\section{List of Economies}

\begin{tabular}{|c|c|c|}
\hline & Name of Economies in English & Name of Economies in Chinese \\
\hline 1 & Anhui & 安徽 \\
\hline 2 & Beijing & 北京 \\
\hline 3 & Chongqing & 重庆 \\
\hline 4 & Fujian & 福建 \\
\hline 5 & Gansu & 甘肃 \\
\hline 6 & Guangdong & 广东 \\
\hline 7 & Guangxi & 广西 \\
\hline 8 & Guizhou & 贵州 \\
\hline 9 & Hainan & 海南 \\
\hline 10 & Hebei & 河北 \\
\hline 11 & Heilongjiang & 黑龙江 \\
\hline 12 & Henan & 河南 \\
\hline 13 & Hong Kong & 香港 \\
\hline 14 & Hubei & 湖北 \\
\hline 15 & Hunan & 湖南 \\
\hline 16 & Inner Mongolia & 内蒙古 \\
\hline 17 & Jiangsu & 江苏 \\
\hline 18 & Jiangxi & 江西 \\
\hline 19 & Jilin & 吉林 \\
\hline 20 & Liaoning & 辽宁 \\
\hline 21 & Macau & 澳门 \\
\hline 22 & Ningxia & 宁夏 \\
\hline 23 & Qinghai & 青海 \\
\hline 24 & Shaanxi & 陕西 \\
\hline 25 & Shandong & 山东 \\
\hline 26 & Shanghai & 上海 \\
\hline 27 & Shanxi & 山西 \\
\hline
\end{tabular}




\begin{tabular}{lcc}
\hline & Name of Economies in English & Name of Economies in Chinese \\
\hline 28 & Sichuan & 四川 \\
29 & Taiwan & 台湾 \\
30 & Tianjin & 天津 \\
31 & Tibet & 西藏 \\
32 & Xinjiang & 新疆 \\
33 & Yunnan & 云南 \\
34 & Zhejiang & 浙江 \\
\hline
\end{tabular}




\section{List of Abbreviations}

ACI

ADB

AIIB

APEC

ASEAN

BBR

BC

BCIM

BOT

CEPA

CPC

CPI

CSP

ECFA

EMU

EU

FBMC

FDI

FGM

FTZ

GAP

GDP

GIS

GMS

GRP

ICT

IPTV

IT

LED

MIT
Asia Competitiveness Institute

Asian Development Bank

Asia Infrastructure Investment Bank

Asia-Pacific Economic Cooperation

Association of Southeast Asian Nations

Bohai Bay Region

Before Christ

Bangladesh, China, India and Myanmar

Build-Operate-Transfer

Closer Economic Partnership Arrangement

Communist Party of China

Consumer Price Index

Comprehensive Strategic Partnership

Economic Cooperation Framework Agreement

Electric Multiple Unit

European Union

Financial, Businesses and Manpower Conditions

Foreign Direct Investment

Flying Geese Model

Free Trade Zone

Good Agricultural Practice

Gross Domestic Product

Government and Institutional Setting

Greater Mekong Sub-region

Gross Regional Product

Information and Communication Technology

Internet Protocol television

Information Technology

Light-emitting Diode

Middle Income Trap 


$\begin{array}{ll}\text { MNC } & \text { Multinational Corporation } \\ \text { MOU } & \text { Memorandum of Understanding } \\ \text { MRT } & \text { Mass Rapid Transit } \\ \text { MS } & \text { Macroeconomic Stability } \\ \text { NGO } & \text { Non-governmental organization } \\ \text { NIE } & \text { Newly Industrialised Economy } \\ \text { NRCMCS } & \text { New Rural Cooperative Medical Care System } \\ \text { ODM } & \text { Original Design Manufacturer } \\ \text { OEM } & \text { Original Equipment Manufacturer } \\ \text { PPP } & \text { Purchasing Power Parity } \\ \text { PRC } & \text { People's Republic of China } \\ \text { PRD } & \text { Pearl River Delta } \\ \text { QLID } & \text { Quality of Life and Infrastructure Development } \\ \text { R\&D } & \text { Research and Development } \\ \text { RCEP } & \text { Regional Comprehensive Economic Partnership } \\ \text { RMB } & \text { Renminbi } \\ \text { SAIC } & \text { Shanghai Automotive Industry Corporation } \\ \text { SME } & \text { Small and Medium-sized Enterprise } \\ \text { SOE } & \text { State-owned Enterprise } \\ \text { TPP } & \text { Trans Pacific Partnership } \\ \text { TWD } & \text { New Taiwan Dollar } \\ \text { UNESCO } & \text { United Nations Educational, Scientific and Cultural Organization } \\ \text { USA } & \text { United States of America } \\ \text { WTO } & \text { World Trade Organization } \\ \text { YRD } & \text { Yangtze River Delta }\end{array}$




\section{Directory of Tables and Figures}

\section{Chapter 1}

Figure 1. GDP of China, Japan, United States of America and East Asia from 1980-2011

Figure 2. The Flying Geese Model

Figure 3. ACI's Competitiveness Framework

Figure 4. Overall Competitiveness Ranking Map 2010

Figure 5. Macroeconomic Stability Ranking Map 2010

Figure 6. Government and Institutional Setting Ranking Map 2010

Figure 7. Financial, Businesses and Manpower Conditions Ranking Map 2010

Figure 8. Quality of Life and Infrastructure Development Ranking Map 2010

Figure 9. Projected Nominal GDP Growth Paths for China, Germany, India, Japan and USA: 2012-2030

Figure 10. Merchandise Trade Structure - 2010 versus 2000

Figure 11. China-ASEAN Total Trade

Table 1. East Asia Economic Development Indicators

Table 2. Overall Competitiveness Rankings, 2010

Table 3. Overall Competitiveness Ranking and Score, 2000-2010

Table 4. Rankings and Scores after What-if Competitiveness Simulation Analysis for Overall Competitiveness, 2010

Table 5. Total Nominal GDP and GDP per capita for World's Major Economies, 2012

Table 6. Relative Importance of USA, EU versus China \& China versus Japan as an Engine of growth for ASEAN-5, 1980-2020

Table 7. Relative Importance of USA versus China \& USA plus Japan versus China as an Engine of Growth for Asian Economies, 2000-2010

Table 8. Relative Importance of EU versus China \& China versus Japan as an Engine of Growth for Asian Economies, 2000-2010

Table 9. Engines of Growth among ASEAN-5, 2000-2010

Table 10. China-ASEAN Connectivity, Collaboration Framework

Table 11. China-ASEAN Connectivity (Yunnan's Projects with ASEAN) — Projects and Implementation Progress

Table 12. China-ASEAN Connectivity (Guangxi's Projects with ASEAN) — Projects and Implementation Progress 
Review 3

Figure 1. The Relationship between ACI's Overall Competitiveness Scores and GDP per Capita (2010)

Figure 2. The Relationships between ACI's Overall Competitiveness Scores and GDP Per Capita (2010, excluding Hong Kong, Macau and Taiwan)

Figure 3. The Relationship between ACI's Overall Competitiveness Scores and GDP (2010)

Figure 4. The Relationship between ACI's Overall Competitiveness Scores and GDP Growth Rate

Chapters 2 to 35

Figure 1. Name of Economy's Overall Competitiveness Ranking (2000-2010)

Figure 2. Name of Economy's Macroeconomic Stability Ranking (2000-2010)

Figure 3. Name of Economy's Government and Institutional Setting Ranking (2000-2010)

Figure 4. Name of Economy's Financial, Businesses and Manpower Conditions Ranking (2000-2010)

Figure 5. Name of Economy's Quality of Life and Infrastructure Development Ranking (2000-2010)

Figure 6. Median Competitiveness Web - Name of Economy (2010)

Figure 7. Maximum Competitiveness Web - Name of Economy (2010)

Table 1. Basic Economic Indicators (2010)

Table 2. Overall Competitiveness Ranking and Score

Table 3. Macroeconomic Stability Ranking and Score

Table 4. Government and Institutional Setting Ranking and Score

Table 5. Financial, Businesses and Manpower Conditions Ranking and Score

Table 6. Quality of Life and Infrastructure Development Ranking and Score

Table 7. Top 20\% Strongest Indicators - Name of Economy (2010)

Table 8. Top 20\% Weakest Indicators — Name of Economy (2010)

Table 9. What-if Competitiveness Simulation Analysis on Overall Competitiveness Ranking and Score (2010)

Table 10. What-if Competitiveness Simulation Analysis on Macroeconomic Stability Ranking and Score (2010)

Table 11. What-if Competitiveness Simulation Analysis on Government and Institutional Setting Ranking and Score (2010)

Table 12. What-if Competitiveness Simulation Analysis on Financial, Businesses and Manpower Conditions Ranking and Score (2010)

Table 13. What-if Competitiveness Simulation Analysis on Quality of Life and Infrastructure Development Ranking and Score (2010) 